\title{
A METHODOLOGY TO TRACK ECONOMIC MOBILITY OF CASTES IN SOUTH INDIAN VILLAGE, CIRCA $1866-2001$
}

Babu N.S. Dasari*

\begin{abstract}
Even though there is a good theoretical discourse on issues of economic mobility and stratification, there are very few empirical studies in the Indian context that gave due recognition to caste in their analyses. The studies that analysed stratification from the perspective of caste, either considered very short period or used 'recall method' mostly confining to survey data. While taking cognisance of intellectual rigour of these studies, we have evolved a 'methodology' using data sources that are least explored, viz., Survey and Settlement Registers and land transactions' data from the Sub-Registrar's office. In this methodology, the concept of surname ('Intiperu' in Telugu) was used to identify all landowners for their castes which paved way to carry out a robust empirical analysis on issues of economic mobility and stratification at a disaggregate level of castes and families. The surname can sometimes be a misnomer. Some surnames exist across different castes. Such limitations were overcome through a very rigorous village study and oral histories of the village. When we applied this methodology in the case of a South Indian village in Krishna district of Andhra Pradesh, onto mapping or surjection is evident between surnames and castes with very few exceptions.
\end{abstract}

Keywords: Methodology, Caste Mobility, Economic Mobility, Village Studies.

\footnotetext{
*Presently, faculty in Economics Department at Rutgers University - Camden, New Jersey, USA.

I dedicate this article to the people of Nandivada village and my beloved father Shri Dasari Hemadri Choudary. Without the support of the people of Nandivada village, this pioneering work would not have been possible. All village elders have been very affectionate in sharing the histories of their families and the village. This helped me in a big way to carry out this work with lots of enthusiasm and passion. I have learnt from my father some of the greatest virtues in life such as: simplicity is the way of life; being truthful no matter whatever the outcomes are; and being kind \& generous which have everlasting impact in my life.

I am indebted to Dean Marchitello, Professors Schiavo and Martin, Rutgers University - Camden, and Vijayendra Rao, Lead Economist, the World Bank for their constant support and encouragement. I am grateful to Professors G. N. Rao, K. Nagaraj, D. Narasimha Reddy, Ajit Menon and David Ludden for sparing their invaluable time and constructive comments.
} 


\section{Introduction}

Caste is a major socio-economic institution in India. While access to economic (land, livestock and cash), political (power) and cultural (education and arts) resources on the one hand and caste status on the other have historically gone together, differences in terms of access to resources have existed amongst families of particular castes. The higher the status of a family within a caste, the greater was its access to one or all resources. Conversely, the lower the status of a family within a caste, lesser was its access to resources. ${ }^{1}$

Over time, such a stratified society underwent changes due to developments that tookplace underpre-colonial,colonial and postcolonial periods. The important developments during the colonial and post-colonial periods in the context of economic mobility of various social groups can be summarised as follows: From the mid-19 $9^{\text {th }}$ century onwards, the rising levels of monetisation of the economy, development of infrastructure (irrigation, rail and road transport and communications), extension of commodity markets both within and outside the country hastened the process of commercialisation in agriculture. In the ryotwari areas, a heavy burden of land revenue constrained agrarian expansion whereas under the zamindari system, the peasantry had to putup with economic and extra-economic coercion exerted by intermediaries. ${ }^{2}$ With the squeezing of economic surpluses from agriculture, upward economic mobility of the peasantry in zamindari areas was either thwarted or slowed down. In spite of the institutional infirmities, a transition from subsistence to commercial agriculture occurred during the second half of the $19^{\text {th }}$ century. This was possible because of the increase in productivity and widening of the commodity markets. The agrarian markets in output, labour, credit and land were activated leading to 'commercialisation in agriculture'. But, these four markets had neither developed synchronously nor autonomously. Often they were inter-locked with each other, thus slowing down the process of transition from subsistence to commercialisation and eventually to agrarian capitalism. In spite of this handicap, at some places where infrastructural facilities (especially irrigation and transport) were provided by the colonial administration, agriculture successfully overcame the institutional infirmities and registered some growth.

Where the given agrarian structure was flexible enough to allow the markets to develop, where commercialisation of agriculture was not forced but voluntary and where intermediate peasant castes were endowed with some land base, there was a possibility of sections of the 'peasant castes'/classes to experience upward economic mobility. However, economic mobility of castes and classes did not occur only in one direction-either upward or downward. Mobility was both ways. In a buoyant agrarian scenario of rising agricultural prices, expanding commodity markets and accrual of some surpluses in the hands of the peasantry, upward economic 
mobility, mostly in the form of expanding land ownership was possible. This did happen in some places. Downward economic mobility seen mostly in terms of land alienation, pauperisation and depeasantisation also occurred in some cases leading to debt traps, an intensified process of extra-economic coercion, high land rents and violent fluctuations in prices of agricultural commodities leading to convulsions in the rural economy. The major peasant castes which experienced these economic mobilities in the country were the Yadavas, Kurmies, Koeries and Jats in the North, Patels and Marathas/ Kumbies in the West and Vokkaligas, Lingayats, Kammas, Reddies, Kapus/Telagas, Gounders, Nadars and Vanniyars in the South. True, these communities were economically differentiated into several classes. ${ }^{3}$ Yet, they cannot be ignored in any discussion on changing land ownership of castes and their economic mobilities.

During the post-colonial period, there were significant changes in the socio-economic and political life of the people in general and agrarian structure and relations in particular. These changes are located in the wider context of development policies and programmes introduced by the State after independence. These interventions are to be seen as a part of the overall strategy of the Indian state to reshape Indian society in terms of its culture, economy, polity and institutions. And above all, the economy was guided through centralised planning under a theoretical framework of a 'mixed economy'.
In the context of agrarian structure and relations, the State-introduced policies aimed at equity and distributive justice. These consisted of land reform policies ${ }^{4}$ including abolition of intermediaries, distribution of waste lands to the poor, a variety of anti poverty measures ${ }^{5}$ including the policies aiming at generation of employment in rural areas, creation of assets for the poor through subsidised credit, distribution of essential commodities through the public distribution system and so on. In addition to these, the State introduced policies to increase productivity of land. The most important of these interventions were: irrigation development through the construction of wells, tanks, canals and major and minor irrigation projects and the introduction of new agricultural technology (popularly known as 'green revolution') in the form of High Yielding Variety (HYV) seeds, chemical fertilisers, pesticides, etc. Furthermore, expansion of institutional credit, crop marketing facilities and price support policies, and expansion of transport and communications were some of the important developments which occurred in rural areas in the postindependence period.

In the above background, if our concern is to capture long-term patterns of economic mobility, primarily through landownership, some of the methodologies and data sources used in mobility studies cannot be adapted for the reasons that we explain in the ensuing sections. Above all, most of the existing empirical studies either ignored 
or given limited attention to 'caste' as an analytical variable. Thus, a methodology was evolved keeping in view both caste and the considerably long time/period of analysis (colonial and post-colonial periods).

This article is organised into five sections. In section I, a discourse on genesis of some of the ideas on economic mobility are presented. Some of the important empirical works on economic mobility and stratification in Indian context are given in section II. In this section, methods used by various mobility studies are highlighted for their merits and limitations in the context of adopting similar methods to analyse long-term patterns of landownership by caste in a South Indian village. In section III, a detailed explanation of proposed methodology and data sources used are given. Section IV makes evident how the proposed methodology is successfully applied in the case of the village in South India, which paved a way to capture long-term patterns of landownership by caste and families. A brief summary is presented in Section V.

\section{Discourse on Economic Mobility}

Although there is a good deal of literature on socio-economic mobility, most of the studies ${ }^{6}$ are confined to social mobility ${ }^{7}$; and many of them are concerned with occupational mobility. However, the shortcomings in the usage of occupation as an indicator of mobility for society as a whole (especially agrarian societies $^{8}$ ) have tended to limit its wider applicability. Hence, Indian scholars have followed an unorthodox way to study social mobility, viz., caste-wise mobility. By using qualitative (historical and anthropological) information, this approach has concentrated mainly on group mobility within the castesystem. ${ }^{9}$ Mobility in terms of cultural variables such as the adoption of high status rituals, customs and marriage alliances struck with'high' castes by 'low' status groups, generally after an improvement in their economic position. ${ }^{10}$ Such analyses are concerned mainly with the upward mobility of a particular group; the downward mobility of members within a social group has not always been given adequate attention. ${ }^{11}$

Apart from sociological and socialanthropological studies of socio-economic mobility, there are studies that have addressed mobility from the point of view of economic stratification of society. Scholars concerned with economic stratification have been inspired by the historical debate between Marxists and Populists in early $20^{\text {th }}$ century Russia. The question whether differentiation was occurring amongst the peasantry was at the heart of theoretical and policy debates in Russia at this time. Following Marx's ideas, Lenin (1899) challenged the views of the Russian Populists and Neo-populists who argued that the peasantry is more or less homogeneous and that capitalism was not an inevitable and necessary process for the development of socialist agriculture in Russia. Lenin argued that capitalism had already 
penetrated into the Russian countryside and a process of 'depeasantisation' or 'differentiation' was taking place leading to the division of the peasantry into two classes, viz., agrarian bourgeoisie and proletariat. He used the concept of 'differentiation' in a specific way; he referred not just to inequality of landholdings, but also to the process of formation of two essential classes of capitalism. Economic factors, according to him, (market forces) were the primary determinants of socio-economic change among the peasantry.

In contrast to Lenin's thesis, Chayanov (1966) argued that the Russian rural economy was best categorised as a 'peasant economy' operating according to its own laws of development rather than to the logic of capitalism. His peasant economy was characterised by farming households which depended on their own family labour and produced primarily for subsistence needs. The central causal mechanism of social change of Chayanov's peasant economy was the changes in life cycle of the family. Chayanov claimed the inequalities in the area sown and the incomes among the Russian peasantry were not socially determined but could be explained in terms of variations in consumer-worker ratios of farm households. As consumerworker ratios changed over the life cycle of farming households, a dynamic process called 'demographic differentiation' or 'cyclical mobility' took place. This cyclical pattern of mobility among all households was stable and was reproduced generation after generation. There was no process of class differentiation and class formation that took place as argued by Lenin. Chayanov's argument implied that no peasant family could ever obtain a permanent position of superiority over others though it might do so temporarily.

Kautsky ${ }^{12}$ (1899) in his analysis of the agrarian situation in Germany in the late $19^{\text {th }}$ century argued that the development of capitalism in agriculture did not necessarily require the dissolution of small-scale peasant production through a process of depeasantisation. His analysis suggested that capitalism could develop without immediate land polarisation and dissolution of smallscale peasant production because cultivation based on family labour was an efficient way of decreasing costs to capitalists. He further argued that small-scale peasant production is functional to the capital and reproduces itself because it serves the interests of capital. It is thus linked to capitalism in such a way that its autonomy is completely undermined. ${ }^{13}$

Shanin (1972) sought to synthesise the two divergent views (Marxists and Populists) on peasant mobility. He felt that peasant mobility in any society with growing market relations was complex. According to him, peasant mobility was of two types: (1) Centrifugal or polarisation, i.e., further impoverishment of poorer families and further enrichment of richer families; (2) Centripetal mobility or levelling tendencies, i.e., relative 
impoverishment of richer families and relative enrichment of poorer families. He noted that both centrifugal and centripetal tendencies had contributed to the differentiation process in Russian peasant society. He further noted 'the socio- economic position of a substantial number of peasant households in the period studied fluctuated with a specific regularity. A peasant household would for some time rise in socio-economic terms within the peasant community and then after reaching some peak undergoes a decline. At a later stage, the same household having reached its lowest ebb might again start to move upward and the whole cycle would recommence' (Shanin, 1972: 76). He calls this process cyclical mobility.

\section{Empirical Studies in Indian Context}

Though at a theoretical level there has been a lively debate among Marxists concerning the impact of capital on agrarian structure, there are a few rigorous Marxist empirical studies. Till the 1970s, most of Marxist empirical studies applied indirect indices of wealth-based categories (income and landholding size) to distinguish classes among the peasantry. Empirical studies of Leninists in the Indian context have drawn on classification schemes designed by Roemer (1982) or Patnaik (1976, 1987), which seek to operationalise ideas of Marxist theory of labour value. Roemer's classification scheme identifies four agrarian classes on the basis of how individuals relate to hiring and selling of labor-power and self-employment. Patnaik's classification scheme identifies the agrarian classes on the basis of a 'labour exploitation' criterion. The labour exploitation criterion (E criterion) classifies households in terms of labour exploitation ratio defined as total use of outside labour divided by family labour days. On the basis of E criterion, Patnaik identifies six agrarian classes. In statistical terms, her schema improves upon Roemer's by replacing a measurement at the level of categories with a ratio that produces a continuous variable (da Corta, 1992).

The studies which have applied Roemer's or Patnaik's criterion (Bardhan, 1984; da Corta and Olsen, 1990 and Patnaik, 1987) generally find a small section of capitalist and rich farmer classes who are primarily dependent on wage labour and a large section of agricultural labour class. It has been assumed that households in these polar classes emerged from those in the middle category which is comparatively smaller in size. This assumption usually has given rise to the conclusion that the Leninist model of differentiation or polarisation is occurring among the peasantry.

On the other hand, most of the empirical studies of Neo-Populists have used landholding size as an index of household's economic position and classified peasant households accordingly into different categories. To address the issues of land polarisation or levelling, they have employed 'household mobility' or 'dynamic study' method which was originally developed by Russian Neo-Populists 
in the late $19^{\text {th }}$ century. This method, unlike most survey methods, does not simply record the extent of inequality at a given point of time, but attempts to follow through with a further survey of the same sample some years later to find out what changes have taken place in the position of each household (Cox, 1986: 39). The data which compare economic position of a household at one period of time with the position at a different point of time are often summarised in transition matrices. Such matrices are used to examine (1) upward or downward mobility of households (2) multidirectional or cyclical mobility and (3) pattern of polarisation (measured as an enlargement of two polar groups) or of levelling (a rise in the middle group). The household mobility studies of Attwood (1979), Cain (1981) and Harriss (1991) have examined the changes in the land ownership pattern in South India and have all reported a trend of decline in inequality of land ownership in their analysis. They have observed a tendency of small landowners gaining land over time and larger landowners losing land. Attwood (1979) and Cain (1981) have used landowning size as an index to classify peasant households into different economic categories. It was generally assumed that the size of landholdings reflects the total household wealth. The declining trend in land inequality is taken as evidence to argue that the Leninist model of differentiation or polarisation is in fact not taking place in South India.
Mostly, studies that have applied the Marxian criterion based on indices developed by Roemerand Patnaikhaveaddressed the issue of stratification at a point of time rather than at multiple time points. The household mobility studies of Attwood (1979), Cain (1981), Harriss (1991), Rajasekhar (1992), Schendel (1981) and Venkateswarlu (1997) have analysed changing landownership of households between the two time points. However, the time periods in these studies are too short to analyse intergenerational mobility. Furthermore, even though Attwood (1979) tried to understand mobility for a period between 1920 and 1970, he used the recall method ${ }^{14}$ while collecting data. He also restricted the definition of family to a single line of descent, tracing it back from the households interviewed in 1970. As different branches of the family may differ in their ownership of land, there is no reason to expect the particular family interviewed in 1970 to represent the status of other siblings or collaterals that branched-off from the ancestral family (Swaminathan, 1988: 169).

Rajasekhar (1992) and Raval (2001) also used recall method in analysing changes between two time points in their respective studies. These studies could not consider the out-migrant households or families of the village in their analysis who by themselves are important in introducing some changes in the village. Lack of detailed accounts of migrant families or households of the village poses a serious problem. The mobility studies by 
Harriss (1991) and Swaminathan (1988) which both used the re-survey method accounted for migration to some extent. However, their studies, by and large, were confined to a period of a decade or less wherein substantial changes are unlikely to have occurred.

Besides the above studies, there were number of studies by economic historians who used archival material and researched on variety of issues ${ }^{15}$ relating to agrarian structure in general and land ownership in particular. By and large, the studies ${ }^{16}$ pertaining to colonial period are with rich descriptive analysis. We see very limited empirical analysis in these descriptions. Nevertheless, these studies give us an idea of archival material where invaluable information is available.

The best-known archival data on land ownership are the Survey and Settlement registers available at the village level from which a rigorous empirical analysis is possible, if an appropriate method is used to translate them into meaningful data. In fact, the most comprehensive statistical research on land distribution in the Madras Presidency, that done by Dharma Kumar (1975), was not directly from Settlement Registers. She used the patta statistics compiled from Settlement Registers. The focus of her study was to address the issue of stratification of the society between the colonial and post-colonial periods. In her study, the land revenues were taken as the proxy for land ownership. She has rightly listed out the limitations of using this method; one of the important limitations being the Inamdari lands which were entitled to pay a very low rate of assessment called the Jodi ${ }^{17}$ or Quitrent would underestimate the land ownership. Her analysis does not deal with the caste-wise inequalities of ownership between the periods since the data does not give any caste-wise ownership figures. Also, her analysis was at an aggregate level of district.

Yanagisawa (1996) made a modest attempt to use the village level Survey and Settlement registers and tried to identify the land owners (pattadars) for their castes. He had attempted to trace the castes of the 26 villages in the Lalgudi taluk of Trichinapally district in Tamil Nadu for 1865 and 1925. He was successful in identifying the pattadars for their castes for 77.4 percent of the total geographical area of these villages. The method he had adopted to identify the castes of the pattadars was primarily through their caste titles as suffixes like lyer, lyyengar, Reddiyar, Mudaliyar, Pillai, etc. Those landowners who were not having such caste titles for their names were left unidentified for their caste. Hence, 22.6 percent of geographical area of these villages was left unidentified for their castes.

In the case of Tamil Nadu, we can hardly think of a method to trace the castes of the landowners of the settlement registers, except by tracing through suffixes, since the nomenclature followed in Tamil Nadu does not retain some links to trace the lineage over generations. In Telugu speaking part of 
the Madras Presidency (the present Andhra Pradesh), tracing the castes of pattadars (landowners) of the Survey and Settlement registers is possible since their naming practice (nomenclature) retains the lineage for generations. Given this phenomenon, we have evolved a methodology through which we have successfully traced the castes of all landowners of Survey and Settlement registers of a village in deltaic Andhra Pradesh.

\section{The Methodology and Data Sources}

In our study to analyse long-term patterns of land ownership of a South Indian village, an application of indices used by Roemer or Patnaik to classify the society into various categories is not possible for want of data for such a long time period of the study (both colonial and post-colonial periods). Likewise, the recall method cannot be successfully deployed due to the long period and obvious reason of lack of memory and recapitulation of events of the past and also because of the large-scale migration that the village had witnessed during the period (more than a century). Thus, we tried to understand economic mobility and stratification in rural society in terms of land ownership from the data available from the Survey and Settlement Registers.

\section{Survey and Settlement Registers}

The British government undertook assessment of lands under the ryotwari settlement for the purpose of determining land revenues. These assessments were generally undertaken every 30 years. For the study village (Nandivada ${ }^{18}$ ), such Survey and Settlement Registers were prepared in the years 1866, 1900 and $1929 .{ }^{19}$ The Survey and Settlement Registers account for the total geographical area of the village which includes both government and private lands of the village. The government lands include the channels, roads and paths, tanks and ponds, burial ground and unoccupied lands. The private lands include the private cultivable titled lands and the village residential area called the gramakantam. All these lands are divided into several survey numbers. In some cases, each survey number is further divided into sub-survey numbers.

In the case of private cultivable titled land, for each plot of land (falling under these survey numbers) information on nature of land (wet / dry), tarams ${ }^{20}$, revenue assessed based on taram (in Rupees), and the extent (in acres) are available. Against each plot of land, it's owner (pattadar) was mentioned. Wherever there are multiple owners of a plot, names of the 'joint-pattadars' were also given.

In our analysis, we focus on private cultivable titled land (hereafter landownership or village land). These lands were patta lands which were assessed for land revenues to be paid to the government. These lands were owned by two kinds of landowners namely the individual pattadars and the joint-pattadars. Individual pattadars were those who solely own 
the piece of land, whereas two or more persons owned joint-pattas. Since we do not have any idea about the shares of ownership on a piece of joint-patta land by the joint-pattadars, we have divided every joint-patta land equally amongst its joint-pattadars. A pattadar might own lands in different survey numbers and hence his ownership of land was arrived at by adding all his lands across different survey numbers in the village land. This procedure was followed for every pattadar. Thus, we have calculated ownership of land in the village by individual landowners or pattadars by summing up all his land (individual and jointpatta ownership) in the village. One of the limitations of this data is that the land owned by the pattadars of this village in other villages escapes our analysis. Another important limitation of this data is that the dimensions of landlessness for the years, 1866, 1900 and 1929 are not captured in our analysis, because these registers only give details about those who own the village land. Besides these Survey and Settlement registers, we already have the data on land owned by different castes in 2001, culled out from the Village Adangal and Chitta registers ${ }^{21}$ which is similar to that of Survey and Settlement registers.

\section{Identification of Castes of Landowners from Survey and Settlement Registers}

Identifying the castes of landowners by 'recall method' was not possible because the land ownership data pertain to 1866 . Some of the individual names were so common across several castes and sometimes the same name recurred in the same family over generations. Also, identifying the caste of the landowner from his caste title (lyer or lyengar in case of Tamil Brahmins, Sarma or Sastry in case of Telugu Brahmins, etc.) was not possible since most of the landowners do not possess these titles. Thus, this method would not facilitate the identification of castes of landowners (pattadars) and hence, we have attempted to identify the castes of the landowners from their surnames (Intiperlu).

\section{The Concept of Surname}

In Andhra, irrespective of caste and religion (both among Hindus and Christians), every Telugu family has a surname. The evolution of surnames in Andhra can be classified broadly into three categories (Yarlagadda, 2002). (1) the surnames, which were derived from the village names ${ }^{22}$ called the ooriperlu; (2) the surnames derived from the occupation ${ }^{23}$ of a group of people and (3) surnames named after one of the famous persons ${ }^{24}$ in the lineage. Therefore, if we try to identify castes through surnames across different parts of Andhra, there would be overlapping of castes across surnames. In other words, a particular surname might occur in more than one caste. However, most importantly, when we try to identify castes through surnames in any specific village, normally there exists an onto correspondence (surjection) between surname and caste, of course with a few exceptions. ${ }^{25}$ 


\section{Surname and Lineage}

The surnames and names of the pattadars (landholders) in the Survey and Settlement Registers were invariably given from 1866 onwards. The surname forms the prefix to the name of every pattadar. The surname passes undisturbed through the male children across generations. Regarding the female child, she gets the surname of her father before marriage and that of her husband after marriage. Hence, surnames are available in all names throughout Andhra Pradesh by sex and religion (Hindu and Christian). Since all Christians in the village have converted from Hinduism, they also invariably possess surnames.

Using this methodology, we were in a position to analyse stratification in terms of land ownership across castes, families (surnames) and size-classes. An analysis of families (surnames) facilitated a further disaggregated analysis of caste.

Using Survey and Settlement Registers, a snap-shot analysis of land ownership of the village is possible. If we are interested in knowing the details of operation of land market during some important periods, say the period during the Depression and Green Revolution, it is possible using yet another important data source available with the SubRegistrar's office.

When we analyse land data available from Survey and Settlement Registers, 1866, 1900, 1929 and village Chitta register 2001, we have land data by caste, surname and size-class for the time points 1866, 1900, 1929 and 2001. Between 1929 and 2001, we have a long gap wherein several important changes might have taken place in the land market due to several socio-economic changes occurring and the impact of State policies like land reforms and Green Revolution. In such a situation, land transaction data available with the Sub-registrar's office will be quite useful. For instance, if we collect land transaction data from 1970 to 2001 from the Sub-Register's office, we will be in a position to arrive at land ownership of the village by caste and surname any time point from 1970 to 2001 . Thus, data from Survey and Settlement registers and land transaction data from Sub-Registrar's office enable us to empirically test various existing hypotheses in stratification debate and land inequalities.

A Census of Nandivada village was conducted in 2001, in order to collect basic and specific information from all the households of the village. Information on caste, religion, land (owned, leased-in, leased-out) and tenancy relations were collected. Basic details such as age, sex, marital status, literacy, primary occupation and secondary occupation of every member of the household were collected. For this purpose, a questionnaire was canvassed across all the households of the village.

In general, economists ignore or do not pay adequate attention to genealogies and/ case studies of families in understanding 
economic mobility. Their primary interest is to quantify economic mobility (upward or downward) and the factors affecting it, not so much about the processes. To understand the socio-economic-cultural processes leading to economic mobility, genealogies and case studies of families were also collected and analysed. Furthermore, the genealogy and case studies will complement and facilitate the interpretation of empirical results obtained from the analyses of Survey and Settlement Registers, 1866, 1900 \& 1929 and Village Adangal, 2001.These families were selected based on prominence of land ownership (past and present). The selection of these families was also done based on contemporary numerical strengths of the families in the village.

An important limitation of Survey and Settlement Registers $(1866,1900 \&$ 1929) and Village Chitta register, 2001 (Adangal) data are that landlessness is not captured in our analysis, because these registers only give details about those who own the village land. We attempt to correct this by using a retrospective question from a census of the village we conducted in 2001 that asked every family about when they migrated into the village. If the family is not registered among landowners during a particular period even though it was residing in the village at that time, it is treated as landless.

\section{Application of the Method}

The above methodology is applied in the case of Nandivada village to analyse the issues of economic mobility and stratification. From the Survey and Settlement Registers of 1866, 1900 and 1929, land transaction data for the periods 1929-1938 and 1970-2001, as also from the Village Census Survey (2001), we have identified 713 distinct surnames (intiperlu) across 22 castes. A detailed listing of all surnames across castes are included in Appendix A. Except for 19 surnames, the rest of the surnames had an onto correspondence to caste (see Appendix B). From all this, we understand that there is an undisturbed onto correspondence (surjection) between surname and caste in Nandivada. An exercise of construction of genealogies of most of the prominent families of the village (past and present) and the discussions with the senior citizens of the village for the oral histories facilitated the identification of surnames for particular castes.

By adopting this methodology, we created a very rich database of landowners by caste, family, sex and size-class at various time points, viz., 1866, 1900, 1929 and 2001. Besides this, we have also created a database of land transaction data from 1929-36 and 1970-2001 obtained from the Sub-Registrar's office. By using this database, the mobilities (both upward and downward) that families and size-classes belonging to various castes experience over generations across time and space are empirically analysed in the context of historical events and developments (micromacro) impacting the region. 
For instance, the year 1900 was the time point wherein the village started to reap the benefits of canal irrigation ${ }^{26}$; and 1929 was the year when the economic depression struck the world. In addition, the period between 1866 and 1900 was characterised by unfavourable commodity markets, especially for rice, due to stiff competition from Burmese rice imports and also because of the impact of a severe famine in the Madras Presidency (1876-78). The period between 1900 and 1929 was characterised by favourable commodity markets after the First World War (1914-18), and stable agriculture due to assured water supply from canal irrigation.

For the purpose of this paper, we will confine our attention to the broader trends of changing land ownership. In other words, a rigorous analysis of Survey and Settlement Data of 1866, 1900, 1929; village Adangal, 2001, land transaction data of 1929-38 \& 19712001; survey data, 2001 and understanding of the processes of socio-economic mobility are beyond the scope of this paper.

An analysis of land ownership across these time points revealed that there were marginal changes of land ownership across the broad social groups (Forward Castes - FCs; Other Backward Castes - OBCs; and Scheduled Castes - SCs) between 1886 and 1929. Of all these broad social categories, FCs owned the largest chunk of land (nearly 85 per cent) in the village in 1866, whereas the rest was owned by both OBCs and SCs (Table 1). But, within the FCs, there was substantial change in land ownership between 1866 and 1900 (first phase). The Kammas gained an additional 15.7 per cent of the village land, whereas the Brahmins and Reddies lost 12.5 and 13.8 per cent of the village land respectively between 1866 and 1900 (Table 1). Interestingly, between 1900 and 1929 (second phase), there was not much change in landownership across broad social groups as well as individual castes. However, the story is not that simple. During this period, a size-class analysis of landowners across castes and changing land inequalities revealed some interesting patterns, and including such analysis in this paper is beyond its scope.

During the post-1929 period, several important events like the Depression, land reforms and new technology had different effects on the village economy; these effects were different for different castes. These were very carefully analysed and interpreted in Dasari (2004). Of the FCs, the major gainers during this period (1920-1970) were the Reddies. They gained nearly an additional 19 per cent of village land, whereas the Kammas did not gain much. The factors that contributed to the low gains among the Kammas and high gains among the Reddies were as follows: The large size landholding Kammas who survived the blow of the Depression had alienated their lands to circumvent land reforms (1961 and 1973) even though they had made substantial economic gains due to the introduction of new technology. The Reddies who were the 
small and middle-size class farmers were also involved in lease and labour markets. The caste hierarchy played an important role in the lease and labour markets, thereby benefiting the FCs more than the SCs. In such a situation, there were some Reddy families who migrated from the dry villages and settled down in Nandivda and registered substantial gains in the land market through lease of land and surpluses generated by leasing in and hiring out labour. The same situation holds good for some marginal and small farmers from among the Kammas too.

Between 1971 and 2001, the share of FCs land in the village land declined from 80.9 to 63.7 per cent. This was largely due to the decline in land ownership of Kammas and Brahmins by 10.3 and 3 per cent respectively. Interestingly, the Reddies who made substantial gains in land between 1938 and 1970 lost 2.1 per cent of village land between 1971-2001. The major gainers during this period were the $\mathrm{OBCs}$ and $\mathrm{SCs}$. Of the OBCs, the Yadavas gained 8.4 per cent of land, whereas the rest of the OBCs do not account for much of the gains in the land market. The Malas (SC) acquired 4.3 percent of village lands between 1971 and 2001 (Table 1). Furthermore, using this methodology, a rigorous empirical analysis patterns of female landownership across 1866, 1900, 1929, 1970 and 2001 was carried out and was linked to various factors, but not limited to pattern of marriages, practice of dowry, migration, impact of land reforms and economic mobility of castes (Dasari, 2016).

Overall, one can say that in a scenario of stable agriculture, opening up of economic opportunities outside agriculture (non-farm employment and investment) and political assertion and lobbying by the less dominant classes and castes, the intra-caste, inter-caste and inter (social) class economic balances are likely to change. This is observable not only at the micro (village) level, but at macro (regional - Delta Andhra) level in contemporary Andhra Pradesh. In addition, these changes give rise to a stratified society, different from the earlier one in terms of its organic structure where the actors at different layers change over generations. 
Table 1: Percentage distribution of Landownership across castes in Nandivada, $1866,1900,1929,1971 \& 2001$

\begin{tabular}{|l|c|c|c|c|c|}
\hline & \multicolumn{5}{|c|}{ Landownership in the Village Land } \\
\hline Caste Name & $\mathbf{1 8 6 6}$ & $\mathbf{1 9 0 0}$ & $\mathbf{1 9 2 9}$ & $\mathbf{1 9 7 1}$ & $\mathbf{2 0 0 1}$ \\
\hline FCs & $\mathbf{8 8 . 4}$ & $\mathbf{8 4 . 5}$ & $\mathbf{8 5 . 1}$ & $\mathbf{8 0 . 9}$ & $\mathbf{6 3 . 7}$ \\
\hline Kamma & 42.0 & 57.7 & 57.5 & 40.2 & 29.9 \\
\hline Reddy & 19.7 & 5.9 & 8.8 & 28.4 & 26.3 \\
\hline Brahmin & 26.7 & 18.2 & 17.1 & 7.0 & 4.0 \\
\hline Others & 0.0 & 2.7 & 1.6 & 5.3 & 3.6 \\
\hline OBCs & $\mathbf{9 . 6}$ & $\mathbf{1 3 . 0}$ & $\mathbf{1 1 . 7}$ & $\mathbf{1 5 . 7}$ & $\mathbf{2 7 . 6}$ \\
\hline Yadava & 2.1 & 3.5 & 5.6 & 8.3 & 16.7 \\
\hline Uppari & 0.1 & 3.2 & 2.0 & 1.3 & 2.9 \\
\hline Turpus & 0.0 & 0.0 & 0.1 & 0.2 & 1.5 \\
\hline Others & 7.2 & 4.6 & 2.7 & 2.5 & 2.9 \\
\hline SCs \& STs & $\mathbf{2 . 0}$ & $\mathbf{2 . 5}$ & $\mathbf{3 . 2}$ & $\mathbf{3 . 4}$ & $\mathbf{8 . 7}$ \\
\hline ALL & $\mathbf{1 0 0}$ & $\mathbf{1 0 0}$ & $\mathbf{1 0 0}$ & $\mathbf{1 0 0}$ & $\mathbf{1 0 0}$ \\
\hline & $(1952.84)$ & $(2172.30)$ & $(2492.97)$ & $(2512.84)$ & $(2512.84)$ \\
\hline
\end{tabular}

Source: Survey and Settlement Register, Nandivada, 1866,

Re-survey and Settlement Register, Nandivada, 1900,

Re-survey and Settlement Register, Nandivad, 1929

Village Adangal, Nandivada, 2001

Index II (1929-38 \& 1971-2001), Sub Registrar's Office, Gudivada.

Note 1: Others in FCs include Kapus, Komatis, Velamas and Rajus.

Others in OBCs include Agnikulakhatriya, Viswa Brahmins, Gowdas, Haridasuslu, Kummari, Muslims, Nayi Brahmins, Padmasaaleelu, Rajaka and Perika

Note 2: Given in the parenthesis are the village land in acres for the respective years.

Note 3: 1970 landownership is calculated from Village Adangal 2001 and land transaction data (1971 - 2001) from Index II from the Sub-Registrar's office, Gudivada. 


\section{Summary}

In an attempt to address some of the issues of economic mobility and stratification in a caste society like India, a methodology is evolved keeping in view the methodologies and data sources used by the existing studies. The studies on mobility in South Asia are few in number. This is probably due to the difficulties involved in the collection of quantitative information on the economic position of households/groups at various time points. These studies drawing their inspiration from the historical debate between Marxists and Populists in early twentiethcentury Russia were not always successful in capturing 'multi-directional mobility'.

Empirical studies of Leninists in the Indian context have drawn on classification schemes designed by Roemer (1982) and Patnaik (1976), which seek to operationalise the ideas of Marxist theory of labour value. These studies ignore any analysis of caste and their analysis mostly confined to a single time point. On the other hand, most of the empirical studies of Neo-Populists have used landholding size as an index of household's economic position and classified peasant households according to different categories. They compare economic position of a household at one point of time with the position at a different point of time, often summarised in 'transition matrices'. Mostly, the duration between these time points is short, and some of the issues pertaining to migration are not adequately addressed. However, all these studies form a good background in evolving a methodology that facilitates an empirical analysis from historical perspective in a caste society like India to address issues of economic mobility and stratification.

In order to overcome some of the limitations of the above studies and focus on long-term patterns of land ownership at a disaggregate level of castes and families, we have used one of the very rich archival sources of land data called the Survey and Settlement Registers which are available from mid $19^{\text {th }}$ century onwards for every 30 years till the first quarter of $20^{\text {th }}$ century, mostly for every ryotwari village in India. At present, a comparable data is available for every village from village Adangal. In these data, the name of pattadar (landowner) including surname and the extent of land owned and details of plot, soil quality of plot, etc., are given.

We have identified castes of landowners through their surnames. Using the concept of surname, we are successfully able to establish an onto mapping between surnames and castes in the village with very few exceptions which are evident from a case study of Nandivada village in Krishna district of Andhra Pradesh. This method can be successfully applied to various other parts of India where an onto correspondence between surnames and castes can be established at a village level and from which an analysis of long-term patterns of land ownership by castes and families is possible, paving way to unveil various aspects of rural economy in several parts of India. 


\section{References}

Alavi, H., (1987), "Peasantry and Capitalism: A Marxist Disclosure”, in Shanin, T (ed), Peasants and Peasant Societies, (Oxford: Basil Blackwell).

Athreya, V. B., (1985), “Gangaikondam, 1916-1984: Change and Stability”, Working Paper No.56, Madras Institute of Development Studies, Chennai.

Attwood, D. W., (1979), "Why Some of the Poor Get Richer: Economic Change and Mobility in Rural Western India", Current Anthropology, 20 (3): 495-516.

Baden- Powell, B. H., (1896), "The Indian Village Community",Delhi: Cosmo Publications.

Bailey, F. G., (1957), "Caste and Economic Frontier: A Village in High Land Orissa”, Manchester: Manchester University Press.

Baker, C. J., (1984), "An Indian Rural Economy, 1880-1955: The Tamilnadu Countryside”, New Delhi: Oxford University Press.

Banaji, J., (1976), “Chayanov, Kautsky, Lenin: Considerations toward a Synthesis", Economic and Political Weekly, 11 (40): 1594-607.

Bardhan, P. K., (1984), "Agrarian Class Formation”, in P. K. Bradhan (ed.), Land Labour and Rural Poverty: Essays in Development Economics, New Delhi: Oxford University Press.

Beteille, Andre., (1965), "Caste, Class and Power: Changing Patterns of Stratification in a Tanjore Village", Berkley and Los Angeles: University of California Press.

Bougle, C., (1958), "The Essence of Reality of Caste System", Contributions to Indian Sociology, 2: 7-30.

Cain, M. T., (1981), "Risk and Insurance: Perspectives on Fertility and Agrarian Change in India and Bangladesh", Population and Development Review, 7(3): 435-74.0

Chaudhuri, Binay Bhushan., (1975), "The Process of Depesantization in Bengal and Bihar", 18851947, Indian Historic Review, 2(1).

Chayanov, A. V., (1966), The Theory of Peasant Economy, Translated by Thorner, D. Kerblay, D. and R.E.F. Smith, Homewood: Irwin.

Cox, T., (1986), Peasants, Class and Capitalism, Oxford: Clarendon Press.

da Corta L. and D. Venkateswarlu., (1992), "Field Methods for Economic Mobility", S. Devereux and J. Hoddinott (eds.), Field Work in Developing Countries (London: Harvester Wheatsheap).

da Corta, L and W. Oslen., (1990), "On the Road to Nimmanapalle: An Empirical Analysis of Labour Relations in Drought-Prone Villages in South India", Discussion Paper Number 66, Department of Economics, Manchester: University of Manchester.

Dasari,Babu N. S., (2004), "Land Caste and Economic Mobility: A Study from Deltaic Andhra", C. 1866-2001, PhD thesis, Madras Institute of Development Studies: University of Madras.

Dasari, Babu N. S., (2012), "Political Economy of Irrigation Development and Patterns of Spatial Inequalities Across Agro-climatic Regions of Krishna District", Journal of Rural Development, 31(3): 257-269. 
Dasari, Babu N. S., (2016), "Dialectics of Female Landownership: A Case Study in Deltaic Andhra", C. 1866 -2001, Journal of Rural Development, 35(4): 531-553.

Deb, P.C., (1975),Social Stratification, Mobility in Rural Setting, Ludhiana: Research Publications.

Djurfeldt, G.,(1982), "Classical Discussions of Capital and Peasantry: A Critique", J. Harris (ed.) Rural Development: Theories of Peasant Economy and Agrarian Change, London: Hutchinson.

Dumont, Louis,(1970),Homo Hierarchicus, London: Paladin, Granda Pub. Ltd.

George, P. T., (1970), "Land System and Legislation in Madras", ArthaVijnana, 12(1\&2): 28-37.

Ghurye, G. S.,(1961),Caste, Class and Occupation, Bombay: Popular Depot.

Glass, D. V.,(1954), Social Mobility in Britain, London: Routledge and Kegan Paul.

Government of Andhra Pradesh, (2001), "A List of Cultivators or Adangal (No.10 Register) of Nandivada Village", maintained by Village Administrative Officer (VAO), Mandal Revenue Office, Nandivada.

Government of Andhra Pradesh, (2001), "A List of Landowners or Chitta (No.3 Register) of Nandivada Village", maintained by Village Administrative Officer (VAO), Nandivada: Mandal Revenue Office.

Government of Andhra Pradesh, Index-Il Register, Nandivada, Sub-Registrar's Office, Gudivada, Various Volumes.

Government of Andhra Pradesh, Re-Survey and Settlement Register, Nandivada, 1900, Gudivada Taluk, Hyderabad: Andhra Pradesh State Archives.

Government of Andhra Pradesh, Re-Survey and Settlement Register, Nandivada, 1929, Gudivada Taluk, Hyderabad: Andhra Pradesh State Archives.

Government of Andhra Pradesh, Survey and Settlement Register, Nandivada, 1866, Gudivada Taluk, Hyderabad: Andhra Pradesh State Archives.

Guhan, S. and John P. Mencher, (1982), "Irualpatty Revisited", Working Paper No.28, Chennai: Madras Institute of Development Studies.

Guha, Sumit, (1987), "The Land Market in Upland Maharastra" c. 1820-1960-1, The Indian Economic and Social History Review, 24(2): 117-144.

Harriss, J.,(1991), "The Green Revolution in North Arcot: Economic Trends", Household Mobility and Politics of an Awkward Class, P. Hazell and C. Ramasamy (Eds.) The Green revolution Reconsidered: The impact of High Yielding Rice Varieties in South India, Baltimore and London: Johns Hopkins University Press.

"Capitalism and Peasant Production in India", in T. Shanin (Ed.) Peasants and Peasant Societies, Oxford: Basil Blackwell.

Hocart, A. M.,(1950),Caste: A Comparative Study,London: Mathew and Co.

Kumar, D., (1975), "Landownership and Inequality in Madras Presidency: 1853-54 to 1946-47", Indian Economic and Social History Review, 12 (3): 229-261.

Lenin, V. I.,(1899),The Development of Capitalism in Russia, Moscow: Progress Publishers. 
Madan, T. N.,(1972), "On the Nature of Caste in India: A Review Symposium on Louis Dumont's Homo Hierarchicus", Contributions to Indian Sociology, 6.

Marriot, McKim,(1965),Caste Ranking and Community Structure in Five Regions of India and Pakistan, Poona: Deccan College.

Mathur, K. S.,(1964), Caste and Ritual in Malva Village, Bombay: Asia Publishing House.

Mayer, A. C.,(1960),Caste and Kinship in Central India, London: Routledge and Kegan Paul.

Miller, S. M., (1960), "Comparative Social Mobility: A Trend Report and Bibliography," Current Sociology, 9: 1-89.

Mukerii Karuna Moy, (1971), "Land Transfers in Birbhum 1928-1955", Indian Economic and Social History Review, 8(3): 241-263.

Patnaik, Utsa, (1976), "Class Differentiation within the Peasantry: An Approach to Analysis of Indian Agriculture", Economic and Political Weekly, 11 (39): A82-A85 \& A87-A101.

Peasant Class Differentiation: A Study in Method and Reference to Haryana, Delhi: Oxford University Press.

Rajasekhar D., (1992),"Economic Mobility of Rural Households: A Study of Kurnool District of Andhra Pradesh", c. 1860- c.1989, PhD Thesis, Thiruvanathapuram: Centre for Development Studies, Jawaharlal Nehru University

Raval, Vikas, (2001), "Agrarian Reform and Land Markets: A Study of Land Transactions in Two Villages of West Bengal, 1977-1995", Journal of Economic Development and Cultural Change, 49 (1): 611-629.

Rao, G. N., (1977), "Agrarian Relations in Coastal Andhra under Early British Rule", Social Scientist, 6(1): 19-29.

Richardson, C.J., (1977), Contemporary Social Mobility, London: Frances Printer.

Richardson, C. J., (1977), “The Problem of Downward Mobility", British Journal of Sociology, 28 (3): 303-320.

Roemer, J.,(1982), A General Theory of Exploitation and Class,Cambridge: Harvard University Press.

Rogoff, Natalie.,(1953),Recent Trends in Occupational Mobility, New York: Free Press of Glencoe.

Schendel, W. Van,(1981), Peasant Mobility: The Odds of Life in Rural Bangladesh, New Delhi: Manohar.

Shanin, T.,(1972),The Awkward Class: Political Sociology of Peasantry in a Developing Society, Russia, 1910-25, London: Oxford University Press.

Sorokin, P. A.,(1954),Social and Cultural Mobility,New York: Free Press.

Srinivas, M. N.,(1952), Religion and Society Among Coorgs of South India, Oxford: Clarendon Press.

Indias Villages, Calcutta: Government of West Bengal.

Some reflections on the nature of caste hierarchy, Contributions to Indian Sociology, 18 (2). 
Sundarayya, P.,(1976), The Land Question, New Delhi: All-India Kisan Sabha.

Swaminathan, Madhura,(1988), "Inequality and Economic Mobility: An Analysis of Panel Data from a South Indian Village", PhD thesis, Oxford University.

Venkateswarlu, D.,(1997), "Changing Agrarian Structure and Relations: Study of a Village in Guntur District 1950-1991", Ph.D thesis, University of Hyderabad.

Weber, Max, (1970), "Class, Status and Party", Gerth, H. H. and Mills C. Wright (Eds.)From Max Weber: Essays in Sociology, London: Routledge and Kegan Paul.

Yanagisawa, Haruka, (1996), A Century of Change: Caste and Irrigated Lands in Tamilnadu 1860s-1970s, New Delhi: Manohar Publishers and Distributors.

Yarlagadda B. Rao, (2002), NamaVignanam, Vijayawada: Niramala publications. 


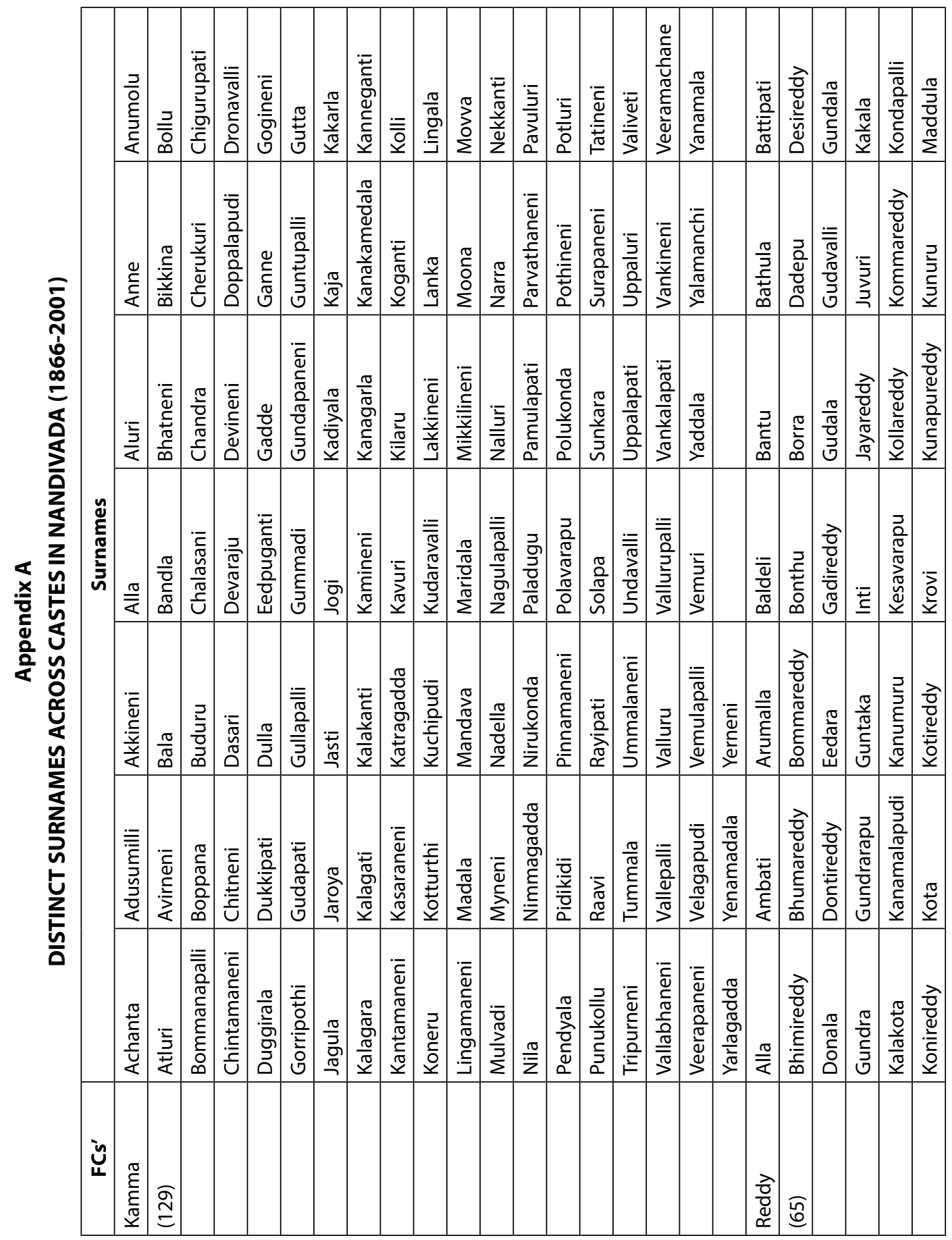




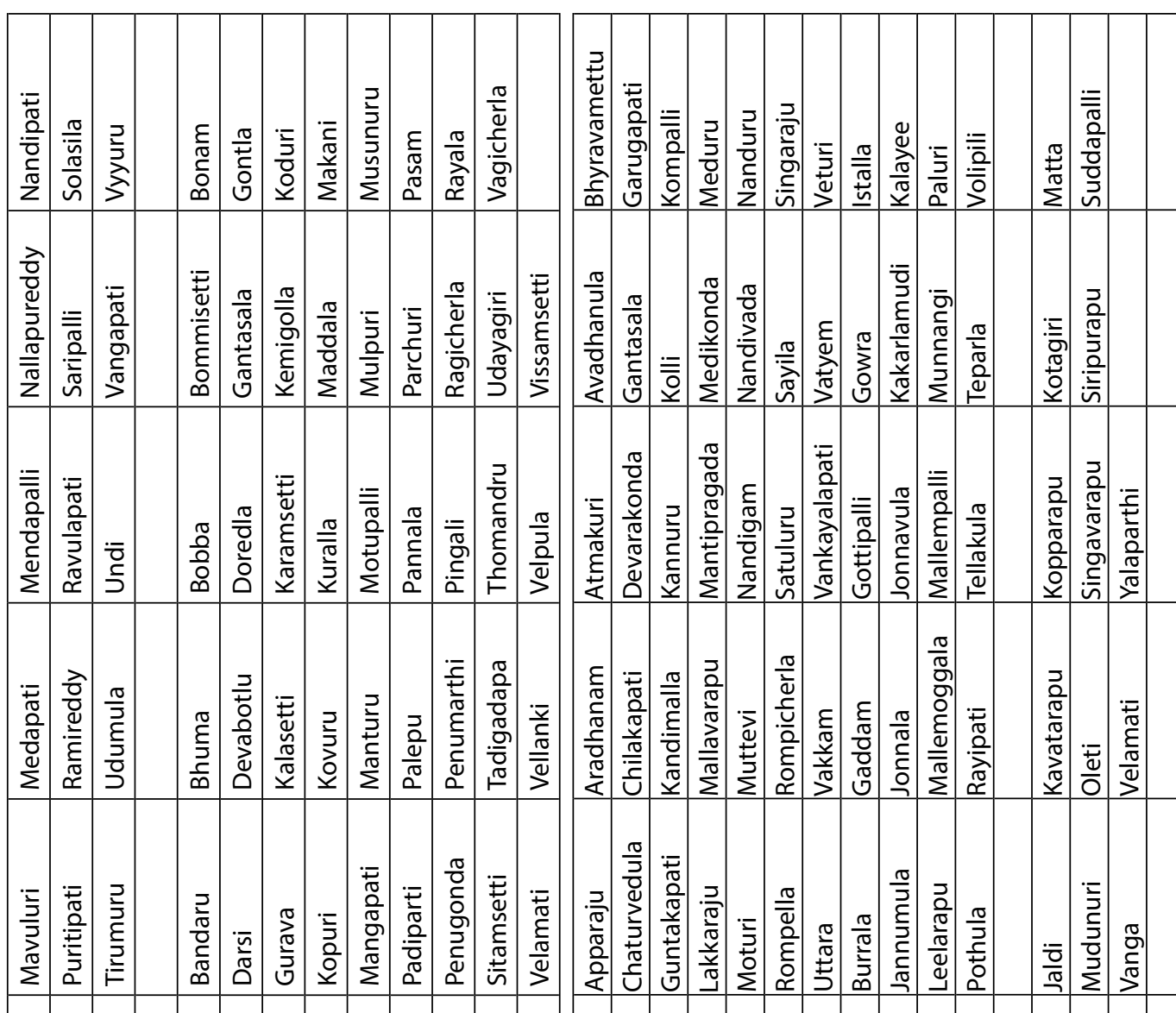

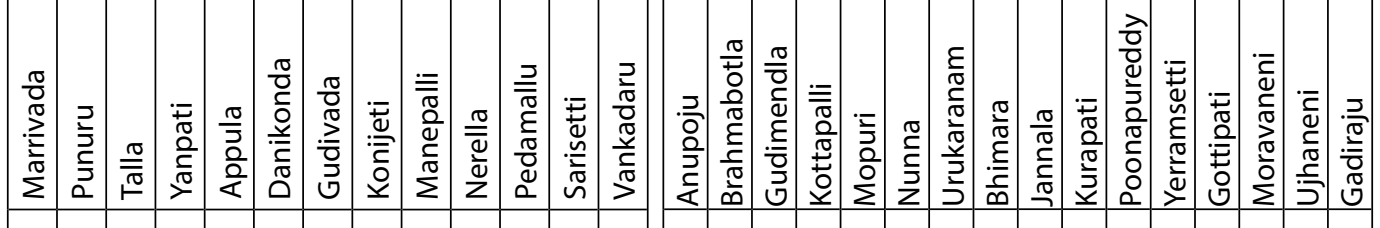

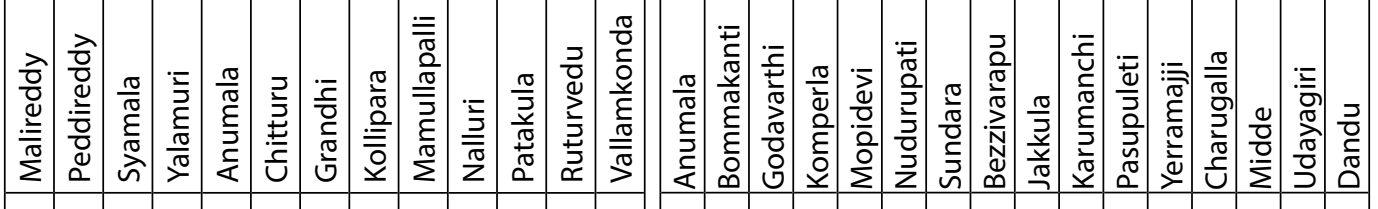

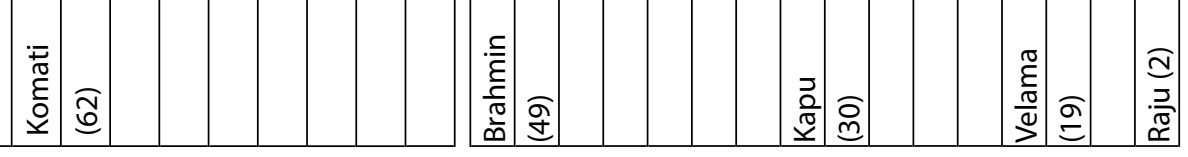




\begin{tabular}{|c|c|c|c|c|c|c|c|c|c|c|c|c|c|c|c|c|c|c|c|c|c|c|c|c|c|c|c|c|}
\hline & 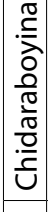 & ن & 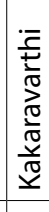 & \begin{tabular}{|l}
$\frac{\pi}{2}$ \\
$\frac{2}{\bar{n}}$ \\
$\frac{0}{0}$ \\
$\underline{0}$ \\
\end{tabular} & 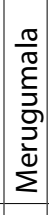 & 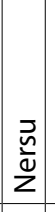 & 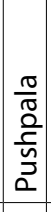 & $\begin{array}{l}\mathbb{0} \\
\stackrel{0}{0} \\
1\end{array}$ & & 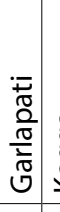 & 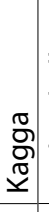 & 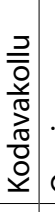 & & 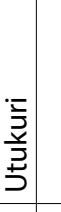 & 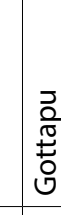 & 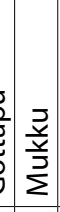 & 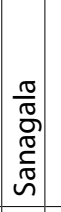 & & 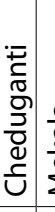 & 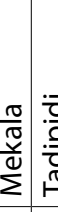 & 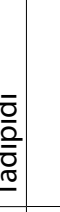 & 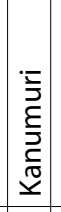 & . & 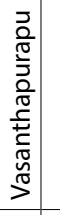 & 吝 & 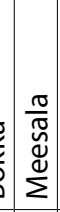 & & 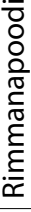 \\
\hline & 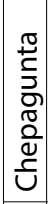 & $\frac{\pi}{\frac{\pi}{2}}$ & 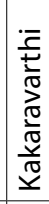 & 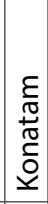 & 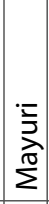 & $\begin{array}{l}\cdot \bar{z} \\
\frac{\pi}{z}\end{array}$ & 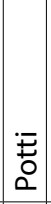 & 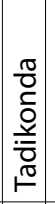 & & 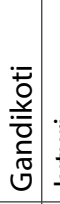 & 言 & 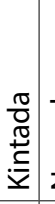 & 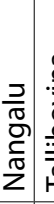 & 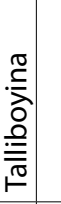 & $\begin{array}{l}\frac{\pi}{2} \\
\frac{0}{0} \\
\frac{0}{\mathcal{N}}\end{array}$ & 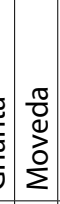 & 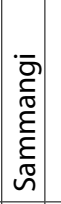 & & $\begin{array}{l}\overline{\frac{0}{a}} \\
\frac{2}{2} \\
\frac{0}{0} \\
\bar{v}\end{array}$ & 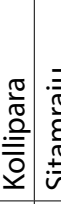 & 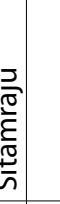 & 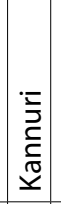 & . & 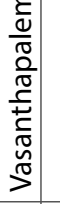 & $\begin{array}{l}\frac{\pi}{\pi} \\
\frac{\pi}{5} \\
\tilde{D} \\
\end{array}$ & $\begin{array}{l}\frac{\pi}{2} \\
\frac{\pi}{2} \\
\sum\end{array}$ & & 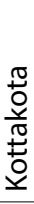 \\
\hline & 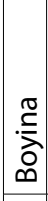 & 旁 & $\begin{array}{l}\frac{\pi}{0} \\
\frac{0}{0} \\
\frac{\pi}{0} \\
\frac{0}{0} \\
\frac{0}{0} \\
\frac{1}{2} \\
0 \\
\end{array}$ & $\begin{array}{l}3 \\
\underline{3} \\
\frac{3}{0} \\
\underline{0}\end{array}$ & 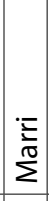 & \begin{tabular}{|l|}
$\frac{\pi}{\pi}$ \\
$\frac{\pi}{2}$ \\
$\frac{5}{\pi}$ \\
$\frac{\pi}{2}$ \\
\end{tabular} & 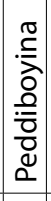 & 㐫 & & $\frac{\frac{\pi}{\pi}}{: \overparen{ত}}$ & 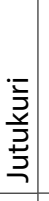 & 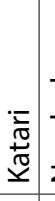 & 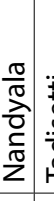 & 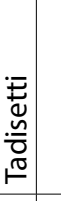 & 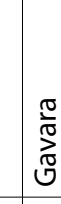 & 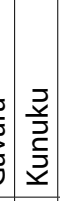 & 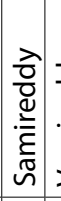 & 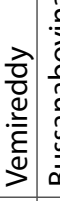 & 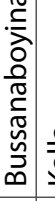 & $\begin{array}{ll}\stackrel{0}{\bar{\pi}} \\
\underline{\underline{x}} \\
\end{array}$ & ภ̊. & $\mid$\begin{tabular}{|c|}
$\frac{\pi}{\pi}$ \\
$\mathfrak{g}$ \\
$\varepsilon$ \\
$\frac{\pi}{\widetilde{T}}$ \\
\end{tabular} & 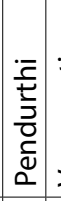 & 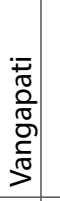 & 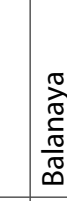 & ș & :- & 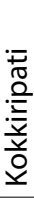 \\
\hline 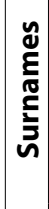 & 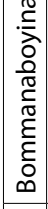 & $\frac{\pi}{\frac{\pi}{\pi}}$ & 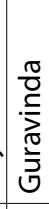 & $\begin{array}{l}\overline{2} \\
\frac{2}{0} \\
\frac{0}{\overline{0}} \\
\frac{\bar{z}}{\bar{y}}\end{array}$ & 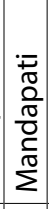 & $\frac{-3}{2}$ & 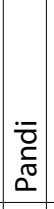 & 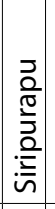 & 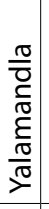 & $\begin{array}{l}\frac{\pi}{\pi} \\
\stackrel{0}{\sigma} \\
\frac{\mathfrak{c}}{\partial} \\
0\end{array}$ & 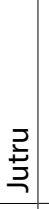 & 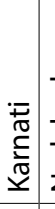 & $\begin{array}{l}\frac{3}{3} \\
\frac{3}{2} \\
\frac{2}{0} \\
\frac{\pi}{0} \\
\frac{\pi}{2}\end{array}$ & 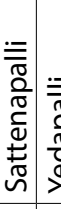 & 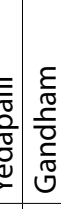 & 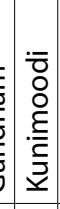 & 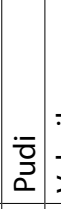 & \begin{tabular}{l|l}
$\frac{\pi}{\bar{n}}$ \\
$\frac{\pi}{2}$ \\
$>$
\end{tabular} & 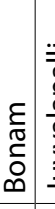 & 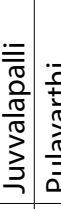 & 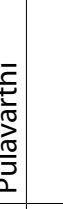 & 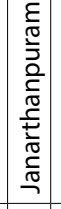 & 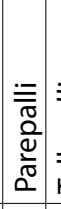 & 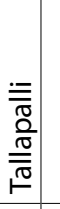 & $\begin{array}{l}\vec{z} \\
\frac{\vec{z}}{\leftrightarrows} \\
\infty\end{array}$ & 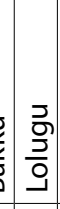 & $\begin{array}{l}\frac{5}{0} \\
\frac{\sigma}{c} \\
\frac{5}{\xi} \\
\text { in }\end{array}$ & $\begin{array}{l}-\overline{0} \\
\overline{0} \\
\underline{0}\end{array}$ \\
\hline & 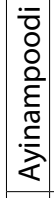 & م & 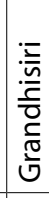 & 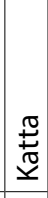 & 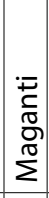 & 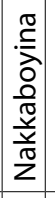 & 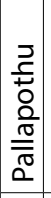 & $\begin{array}{c}: \overline{\bar{\sigma}} \\
\tilde{g} \\
\varepsilon \\
\bar{d} \\
\widetilde{\simeq}\end{array}$ & 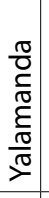 & 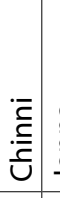 & 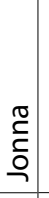 & 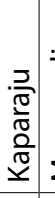 & 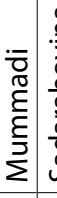 & 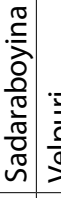 & 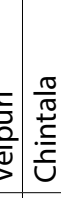 & 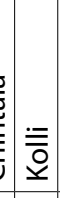 & 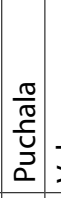 & $\begin{array}{ll}\frac{\pi}{2} \\
\frac{\pi}{2} \\
>\end{array}$ & 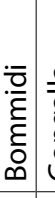 & 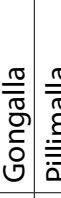 & 离 & 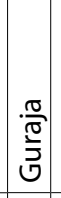 & 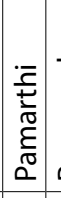 & 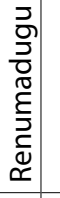 & 定 & 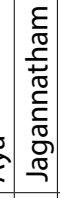 & 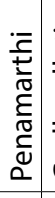 & 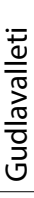 \\
\hline & . & 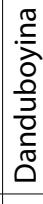 & 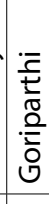 & $\begin{array}{l}\frac{\pi}{J} \\
\frac{7}{0} \\
\frac{1}{\pi} \\
\underline{x} \\
\end{array}$ & తి & 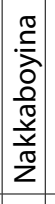 & 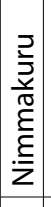 & : & 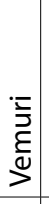 & 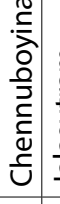 & 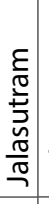 & . & $\begin{array}{l}\stackrel{0}{c} \\
\stackrel{2}{0} \\
\frac{0}{0} \\
\frac{0}{0} \\
\frac{0}{2} \\
\Sigma\end{array}$ & 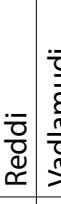 & 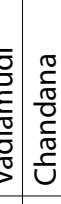 & 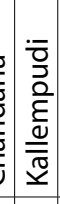 & 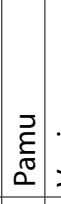 & $\begin{array}{l}\frac{2}{2} \\
\frac{0}{0} \\
\frac{0}{\frac{0}{2}} \\
\frac{1}{5} \\
>\end{array}$ & 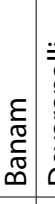 & 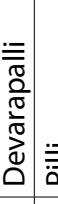 & 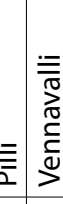 & 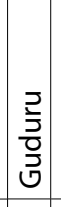 & 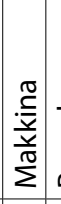 & $\begin{array}{l}\frac{\pi}{\pi} \\
\sum_{\pi}^{\pi} \\
\check{c}\end{array}$ & 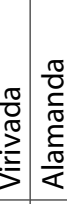 & 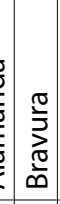 & 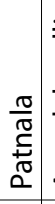 & $\begin{array}{l}\overline{\bar{\pi}} \\
\frac{0}{\frac{1}{0}} \\
\frac{\pi}{\frac{\pi}{0}} \\
\frac{0}{2} \\
\frac{\varepsilon}{<}\end{array}$ \\
\hline & \begin{tabular}{|c|}
$\frac{0}{T}$ \\
$\frac{0}{0}$ \\
$\frac{0}{0}$ \\
$\frac{9}{2}$ \\
\end{tabular} & 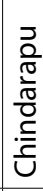 & $\frac{0}{\overline{0}}$ & 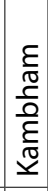 & 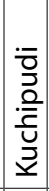 & \begin{tabular}{|c|}
$\bar{\pi}$ \\
$\frac{2}{0}$ \\
$\frac{0}{3}$ \\
$\frac{3}{0}$ \\
$\frac{\pi}{2}$ \\
\end{tabular} & 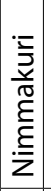 & 忢 & $\begin{array}{l}\frac{\pi}{\grave{2}} \\
\stackrel{\Phi}{>}\end{array}$ & $\frac{\frac{\pi}{\pi}}{\frac{\pi}{\pi}}$ & $\begin{array}{l}\stackrel{+}{0} \\
\stackrel{0}{0} \\
\overline{0} \\
0 \\
\end{array}$ & 童 & 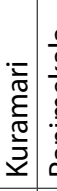 & 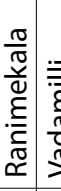 & 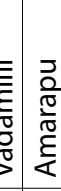 & 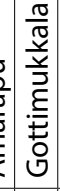 & $\underbrace{ \pm}_{\Sigma}$ & 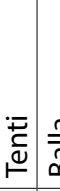 & $\stackrel{\pi}{\overline{\bar{\pi}}}$ & 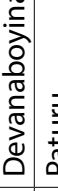 & 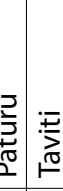 & : & 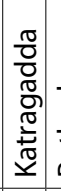 & 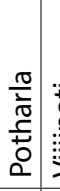 & 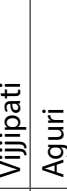 & 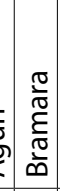 & 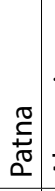 & \\
\hline 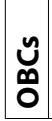 & 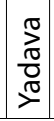 & & & & & & & & & $\begin{array}{l}\frac{1}{0} \\
\frac{0}{2} \\
\frac{2}{2}\end{array}$ & & & & & $\begin{array}{l}\frac{\tilde{E}}{0} \\
\frac{\pi}{0} \\
\frac{1}{2} \\
\end{array}$ & $\underset{\mathrm{O}}{\mathrm{O}}$ & & & 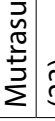 & & & 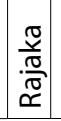 & $\stackrel{\widetilde{\mathfrak{z}}}{\mathrm{g}}$ & & $\begin{array}{l}\stackrel{0}{\pi} \\
\stackrel{5}{F}\end{array}$ & $\stackrel{\sigma}{\varrho}$ & & \\
\hline
\end{tabular}




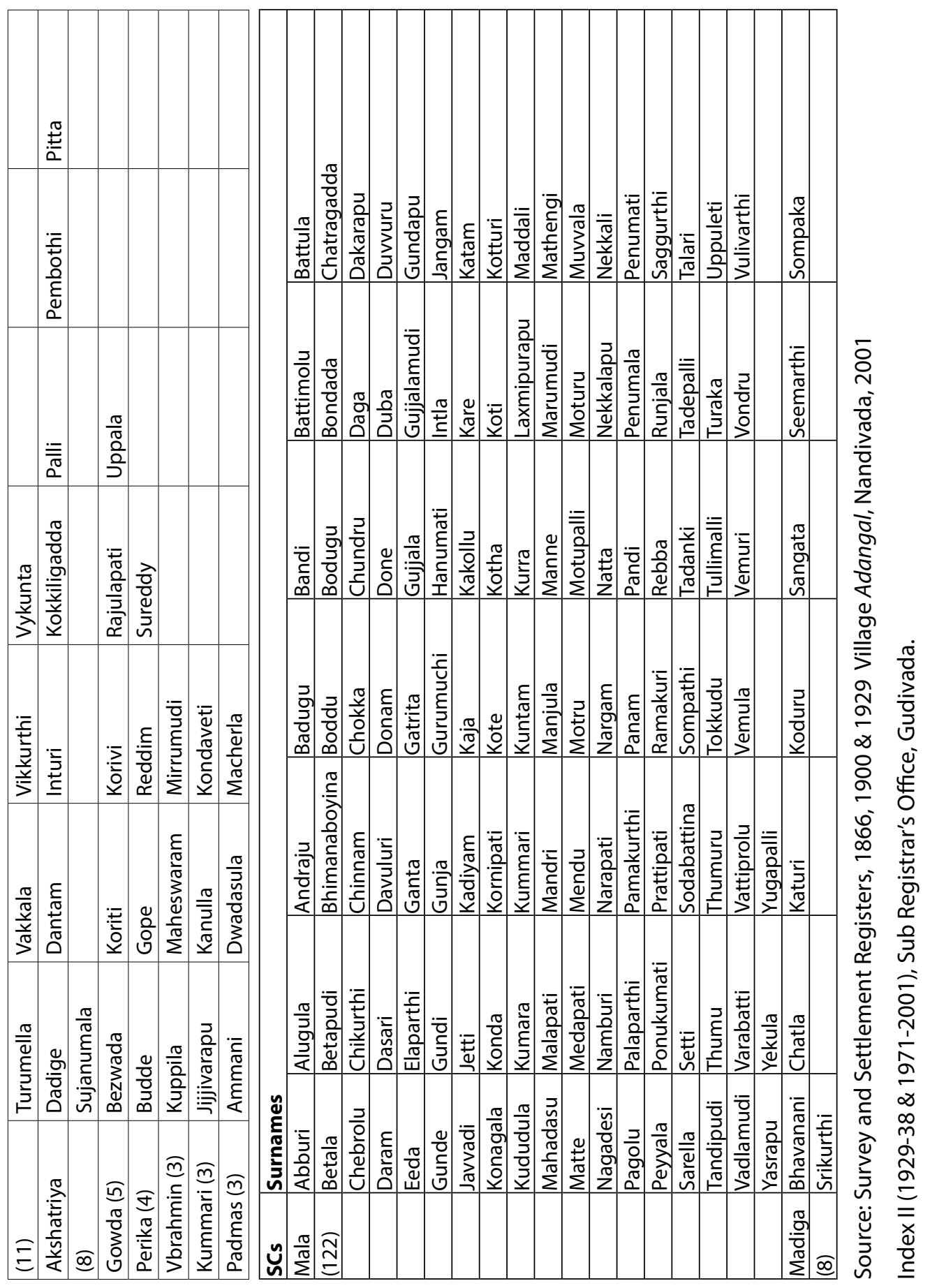




\section{Appendix B}

\section{List of Surnames Occurring in More than One Caste in Nandivada}

\begin{tabular}{|c|c|c|}
\hline Index & Surname & Castes \\
\hline 1 & Alla & Kamma and Reddy \\
\hline 2 & Anumala & Brahmin, Komati \\
\hline 3 & Bonam & Komati, Mutrasulu \\
\hline 4 & Dasari & Kamma and Mala \\
\hline 5 & Gantasala & Brahmin, Komati \\
\hline 6 & Kaja & Kamma and Mala \\
\hline 7 & Katragadda & Kamma and Rajaka \\
\hline 8 & Kolli & Brahmin, Kamma and Kvelama \\
\hline 9 & Kollipara & Komati and Mutrasulu \\
\hline 10 & Kuchipudi & Kamma and Yadava \\
\hline 11 & Medapati & Reddy and Mala \\
\hline 12 & Motupalli & Komati and Mala \\
\hline 13 & Nalluri & Kamma and Komati \\
\hline 14 & Pandi & Mala and Yadava \\
\hline 15 & Rayapati & Kamma and Kapu \\
\hline 16 & Vadlamudi & Mala and Uppari \\
\hline 17 & Vangapati & Rajaka and Reddy \\
\hline 18 & Velamati & Komati and Velama \\
\hline 19 & Vemuri & Kamma, Mala and Yadava \\
\hline
\end{tabular}

Source: Same as in Appendix A.

\section{(Endnotes)}

1 These ideas are well documented and theorised in sociological and anthropological studies. For instance, see Bailey (1957); Bougle (1958); Dumont (1970); Ghurye (1961); Hocart (1950); Madan (1972); Marriot (1965); Mathur (1964); Mayer (1960); Srinivas $(1955,1984)$ and Weber (1970). Caste, in these studies, is equated with social stratification encompassing economic and political aspects of social status.

2 These ideas were well argued and documented in coastal Andhra by Rao (1977) and in Madras Presidency by George (1970). 
3 According to Patnaik (1987), Sundarayya's, The Land Question is the only published attempt in India which applies the Leninist concept of class, after the discussion of different classes, to the analysis of data. The analyses of class structures and some economic characteristics of two villages in Andhra Pradesh - Anantavaram and Kaza revealed that peasants or peasant castes themselves can be categorised into rich peasants, middle peasants and poor peasants, based on the criterion of their level of participation in agricultural operations (Sundarayya, 1976).

4 As a part of an overall strategy to bring about changes in the agrarian structure, a number of institutional changes were introduced through legislations by the union and State governments in the 1950s and 1960s. In Andhra Pradesh, these included the Estates Abolition Act, 1948; Andhra Tenancy Act, 1956; Hyderabad Tenancy and Agricultural Act, 1950; Andhra Pradesh Land Reform (ceiling on holdings) Acts, 1961 and 1973.

5 Since independence, both the union and State governments have introduced a number of anti-poverty measures to help the rural poor. Union government policies include, the community Development programmes of the early 1950s, the Small and Marginal Farmers Development Programmes of the early 1970s (S.F.D.A and M.F.D.A), which were later brought under a common programme called the Integrated Rural Development Programme (I.R.D.P) in 1978. In addition to the I.R.D.P., the union government also introduced a new programme called Jawahar Rojgar Yojana (J.R.Y), aimed at creation of additional employment in the rural areas. In addition to these policies of the union government, the government of Andhra Pradesh also introduced a number of special programmes such as the Subsidy Rice Scheme and Old Age Pensions Scheme.

6 Some of the studies on social mobility are Deb (1975); Glass (1954) and Rogoff (1953).

7 Social mobility involves changes in the status of individuals and groups in a stratified society taking an upward or downward direction. Changes in status may happen in three ways (i) vertical mobility (involving a change in social or economic rank) (ii) horizontal mobility (involving a change in occupation but no change in rank) and (iii) spatial mobility (change in location or migration with or with out change in rank).

8 The difficulty of understanding occupational mobility in agrarian societies is the result of a number of factors: the inadequacy of the concept of occupational change in the context of agriculture; the difficulties in knowing upward or downward mobility of a farmer or worker; and lack of quantitative data on shifts in occupation in agriculture (Miller, 1960: 61).

9 See for instance, Athreya (1985); Beteille (1965); Guhan and Mencher (1982) and Srinivas (1952).

10 Education is also cited as an important reason for the upward mobility of lower caste groups. In addition, shifting cultural values due to contact and communication between members of different strata; the flow of cultural values is generally from city to country (Sorokin, 1954). M.N. Srinivas defined sanskritisation as a process by which "a low or middle Hindu Caste, or tribal or other group, changes its customs, ritual ideology, and way of life in the direction of a high and frequently twice-born caste. Generally, such changes are followed by a claim to a higher position in the caste hierarchy than that traditionally conceded to the claimant class by the local community (Srinivas, 1952). 
11 C. J. Richardson primarily concentrates on the causes of downward economic mobility. While discussing the two existing theories that explain downward mobility viz., social causality explanation (occurring due to mental and physical illness, alcoholism, addiction and family disorganisation) and meritocratic explanation (outcome of meritocratic norms and the diminishing significance of particularistic-ascriptive norms which are primarily due to openness of the sons born in advantaged strata), he comes up with an explanation of downward mobility as a two-generation process of status consolidation (Richardson, 1977).

12 Kautsky's Die Agrargrage (translated as Agrarian Question) was published in 1899. Some extracts were published in English in Banaji (1976).

13 For a detailed discussion on Kautsky's views on the relationship between capital and peasantry see Alavi (1987); Banaji (1976); Djurfeldt (1982) and Harriss (1987).

14 In this method, land ownership data is collected from the present households as well as their respective parent households/families in the past. Emphasis is laid on the pattern of partition and its effects on changing land ownership.

15 Some of the issues were: one, whether commercialisation of agriculture and monetisation of economy led to the impoverishment of the peasant leading to transfer of lands from the peasant to the moneylender or landlord; two, how the emergence of land market with the creation of private property in land influence the agrarian structure historically; three, in the context of land reforms, patterns of land ownership were addressed for it's impact on the society; four, who were the class of landowners that reaped the benefits of New Technology.

16 Some of the important studies under this category were Chaudhuri (1975), Guha (1987), Mukerji (1971).

17 Land assessed at half-rates for temples or in consideration of service. In other words, an easy or quit rent.

18 Nandivada is a multi-caste deltaic village in Krishna district of Andhra Pradesh in South India. The village had the benefits of assured irrigation from the last quarter of $19^{\text {th }}$ Century due to the construction of Krishna anicut across River Krishna in 1855. Due to assured irrigation, Paddy was gown as commercial crop and experienced growth in agriculture. The village also experienced the shocks of Great Depression (1929-35) and recovered from it during the inter-war periods. Later, some of the policy measures of the State viz., land reforms and Green Revolution did have an impact on agriculture and agrarian structure of the village. Besides all these, due to rapid migration of population in both the directions, the village underwent substantial changes during the last quarter of $20^{\text {th }}$ century (Dasari, 2004).

19 For the years 1900 and 1929, these are called the Re-survey and Settlement Registers.

20 The Settlement Department divides the soils into series according to the commonly recognisable soil types, sub divides series into classes with reference to their mechanical composition, and then divides classes into sorts or grades with reference to their chemical and physical properties and other circumstances affecting their fertility. In addition to this, villages are grouped according to their situation with reference to proximity to markets, communication facilities and climate. This grouping is independent of soil fertility. Tarams for different plots of lands are arrived at taking these two aspects into consideration. For details see Baden-Powell (1896: 61). 
21 Adangal and Chitta registers deal with surveyed land within the village. While the Adangal is the cultivation account register maintained by the Village Administrative Officer (VAO), the Chitta register gives detailed accounts of land holding with regard to survey number, landowners, etc. These registers are cross checked with a similar register called pattadar pass book register maintained by the VAO.

22 For instance, Yarlagadda is both a village name and surname. His hypothesis was that the ancestors of the village who have migrated to different places over time were called as Yarlagaddas might belong to various castes (Yarlagadda, 2002). The village names themselves were names based on either the topology of the place or availability of certain uncommon plants, etc. For a detailed discussion on village names in Andhra Pradesh, see (Yarlagadda, 2002).

23 For instance, during the olden days, some Brahmins donated cattle for the functioning of the temples in the village. These cattle had to be looked after by some one and hence an occupation came into vogue. The occupation of looking after the cattle was called 'Kilaru' and the descendants of this occupation derived 'Kilaru' as their surnames.

24 For instance, surnames like Pinnamaneni, Kommaneni, Vasireddy and Konnapreddy would belong to this category. It is easy for this class of surnames to draw an onto correspondence between surnames and castes because identification of prominent people from this caste is an easy task.

25 I am benefited from a personal interview with Prof. Yarlagadda Bala Gandhara Rao, an expert on Telugu names. He opined that an onto correspondence or surjection exists between surname and caste within a single village. However, it does not apply to the whole of Andhra Pradesh.

26 Dasari (2012) analysed the phases of irrigation and spatial inequalities in Krishna district. Since Nandivada village is the head region of the Krishna anicut, it was irrigated in the first phase. 